\title{
Magie v Lex Duodecim tabularum
}

\author{
Pavel Záliš
}

Právnická fakulta, Masarykova univerzita

Kontaktnie-mail: zalis@akzalis.cz

\section{Magic in the Twelve Tables}

\begin{abstract}
:
The article deals with the relationship of Roman law and magic from the perspective of Twelve Tables. It deals mainly with two provisions of the eighth table of the Twelve Tables QUI MALUM CARMEN INCANTASSIT and QUI FRUGES EXCANTASSIT. The paper offers closer insight into the perception of magic by the Romans when it comes to its prohibiting and punishing its practice. It also compares the individual ancient sources that deal with these provisions. The aim of this paper is to provide a broader perspective of the context of magic in early Roman law.
\end{abstract}

\section{Keywords:}

magic; carmen; malum carmen; excantare; qui malum carmen incantassit; qui fruges excantassit; ř́mské právo; zákon XII desek

\section{Klíčová slova:}

magie; carmen; malum carmen; excantare; qui malum carmen incantassit; qui fruges excantassit; Roman law; Twelve Tables

DOI: $10.14712 / 2464689 X .2020 .33$

Problematika magie v římském prostředí a speciálně v právu představuje zajímavou a zároveň velmi specifickou oblast. I když většina klasických prací týkající této oblasti pochází z první třetiny 20 . století, ${ }^{1}$ tak v posledních letech se toto téma těší zvýšenému

HUVELIN, P. La notion de l',,iniuria “ dans le très ancien droit romain. Lyon: A. Rey, 1903; FRAENKEL, E. Review of Zauberei und Recht in Roms Frühzeit. Ein Beitrag zur Geschichte und Interpretation des Zwölftafelrechtes. Gnomon, 1925, roč. 1, č. 4; BECKMANN, F. Zauberei und Recht in Roms Frühzeit. Ein Beitrag zur Gechichte und Interpretation des Zwölftafelrechtes. Münster: W. Nolte, 1923; VOIGT, M. 
zájmu. $^{2}$ Hned v úvodu je nezbytné zdůraznit, že jakýkoli výzkum magie v Zákoně XII desek je do jisté míry komplikovaný, a to ze dvou odlišných, byt' souvisejících důvodů. Na jedné straně představuje zásadní obtíže skutečnost, že se tento zákon dochoval pouze ve fragmentární podobě, nevyjímaje ustanovení vztahující se právě k magii, a zároveň na straně druhé existují nemalé obtíže spojené s užitím pojmu „magie“, jakožto interpretační kategorie. Oba problémy jsou nevyhnutelně provázány a do určité míry determinují úspěchy při jejich pochopení. Naše znalosti týkající se Zákona XII desek závisí na citacích a odkazech antických autorů, kteří převážně žili v rozmezí od prvního století před naším letopočtem do čtvrtého století našeho letopočtu. I když v tomto období docházelo k rozkvětu literární činnosti, tak zájem o Zákon XII desek postupně v praktickém životě upadal, a to v návaznosti na mohutný rozvoj praetorského práva, které Zákon XII desek po obsahové stránce do značné míry nahrazovalo. Zákon tedy prritahoval pozornost autorů zabývajících se současnými právními aspekty v širším, často historickém kontextu. Patří mezi ně zejména Cicero, Macrobius, Festus nebo Plinius starší. Naneštěstí tito autoři jej zmiňují pouze zkratkovitě a heslovitě, nejčastěji za účelem podpořit jiný argument vztahující se k nějaké aktuální problematice, kterou právě řešili. Z tohoto důvodu musíme na jejich citace a interpretace Zákona XII desek pohlížet touto perspektivou, tedy že mohou být ve větší či menší míře oproti originálu pozměněny, aby jimi řešenou problematiku bud' podpořily, nebo naopak vyvrátily.

Druhé neopominutelné úskalí, které s daným tématem souvisí, je terminologie. ${ }^{3} \mathrm{~V}$ době vzniku Zákona XII desek totiž Římané neznali pojem „magie“ či „,magický“, jelikož ten se dostal do Ř́ma přes Řecko mnohem později (nejdřive v 1. století před n. 1.). Slovo magie původně označovalo západoiránské etnikum a později kněžskou kastu v Perské ř́iši. ${ }^{4}$ To je důvod, proč latina neobsahuje takové pojmy a ani je obsahovat nemůže. Nicméně magické praktiky, tak jak je dnes nazýváme, byly součástí každodenního života Římanů a jako takové byly úzce provázány s římským náboženstvím; tvořily jejich integrální součást, o čemž svědčí např́iklad ustanovení Zákona XII desek (Tab. II. 3): Cui testimonium defuerit, is

Die XII Tafeln. Leipzig: A. G. Liebskind, 1883; MOMIGLIANO, A. Review of L. Robinson: Freedom of Speech in the Roman Republic. The Journal of Roman Studies, 1942, č. 32.

2 PHILLIPS, C. R. The sociology of religious knowledge in the Roman empire to A.D. 284. ANRW II, 1986, roč. 16, č. 3; PHILLIPS, C. R. Nullum Crimen sine Lege: Socioreligious Sanctions on Magic. In: FARAONE, A. C. - OBBINK, D. (ed.). Magika Hiera: Ancient Greek Magic and Religion. New York: Oxford University Press, 1991; GORDON, R. Aelian's Peony: the location of magic in Graeco-Roman tradition. Comparative Criticism, 1987, č. 9; GORDON, R. Imagining Greek and Roman Magic. In: ANKARLOO, B. - CLARK, S. (ed.). Witchcraft and magic in Europe: Ancient Greece and Rome. Philadelphia: University of Pennsylvania Press, 1999; GRAF, F. Magic in the Ancient World. Překl. PHILIP, F. Cambridge, Mass.: Harvard University Press, 1999; HOFFMAN, C. A. The Idea of Magic in Roman Law. Berkeley: University of California, 2002; RIVES, J. B. Magic in the XII Tables Revisited. The Classical Quarterly, 2002, roč. 52, č. 1; RIVES, J. B. Magic in Roman Law: The Reconstruction of a Crime. Classical Antiquity, 2003, roč. 22, č. 2; VERSNEL, H. S. - FRANKFURTER, D. - HAHN, J. Magical Practice in the Latin West. London, Boston: Brill, 2010.

3 Jak Rives trefně poznamenal: „Jedním z nejvíce přetrvávajících problémů ve studiu magie ve starověkém Středomoří je samotný pojem ,magie“."RIVES, J. B. Magus and Its Cognates in Classical Latin. In: Magical Practice in the Latin West. London, Boston: Brill, 2010.

4 SKŘEJPEK, M. Ius et religio: právo a náboženství ve starověkém Římě. Pelhřimov: Vydavatelství 999 , 1999, s. 165. 
tertiis diebus ob portum obuagulatum ito. ${ }^{5}$ Jedná se o ustanovení, na jehož základě se mohl účastník sporu dovolávat svědectví jiné osoby tím, že chodil každý třetí den k jeho dveřím a pronášel magické formule, které dveře otevřou a přimějí svědka poskytnout svědectví u soudu. ${ }^{6} \mathrm{Na}$ tomto př́padu je velmi dobře patrné ono zmiňované úskalí: Na první pohled totiž není zřejmé, že se jedná o ustanovení mající jakoukoli souvislost s magií. Nadpřirozené konotace tomuto ustanovení dává až slovní spojení obvagulatum ito ${ }^{7}$ mající původ v nejstarší latině.

Klíčová pro studium magie v Zákoně XII desek jsou ovšem jiná ustanovení, konkrétně VIII. desky (1a. a 8a.), která postihovala praktikování černé magie. Obě nám zprostředkoval Plinius starší, který je zachytil ve své encyklopedii Naturalis historia. Plinius konkrétně uvádí:8 ... in XII tabulis verba sunt: "QUI FRUGES EXCANTASSIT”, et alibi: “QUI MALUM CARMEN INCANTASSIT”, ${ }^{9}$ Jedná se naneštěstí o jediný antický literární pramen, který cituje obě „magická“ ustanovení Zákona XII desek doslovně. I když i jiní autoři tato ustanovení zmiňují, nelze s naprostou jistotou toto doslovné znění verifikovat. S ohledem na jejich význam se budeme zabývat oběma zmíněnými ustanoveními Zákona XII desek v kontextu jiných pramenů, které se do dnešní doby dochovaly, s cílem zjistit jejich význam, obsah a důvod, proč byly zařazeny v polovině pátého století před naším letopočtem do prvního římského kodifikačního díla.

\section{QUI MALUM CARMEN INCANTASSIT}

Ustanovení Zákona XII desek QUI MALUM CARMEN INCANTASSIT v podání Plinia staršího postihuje zpívání zlé písně, tedy malum carmen, proti komukoli ve snaze mu přivodit újmu. Zákaz praktikování magie se vztahuje na veškerou škodlivou magii bez ohledu na předmět, původce nebo adresáta. ${ }^{10}$ Jedná se, jak bychom dnes řekli, o jakousi generální klauzuli nebo obecnou zákonnou prevenci proti škodám způsobeným magickými praktikami. Kontext, v němž Plinius starší odkazuje na píseň (carmen) svědčí o tom, že ji chápal jako vyjádření něčeho, co negativně ovlivňuje okolní svět. Můžeme jen litovat, že je nejen jediným antickým autorem, který cituje doslovné znění tohoto ustanovení Zákona XII desek (a navíc v nekompletní podobě), ale též jediným autorem, který zmiňuje sousloví malum carmen ve smyslu škodlivé kouzlo či zaklínadlo v souvislosti se zkoumaným fragmentem Zákona XII desek.

Podíváme-li se na samotný obsah ustanovení, zjistíme, že slovesa cantare a jeho slovní derivát incantare lze přeložit jako „zpívat proti““, což značí různé způsoby užití zpěvu

5 „Komu bude chybět svědectví, at' chodí každý třetí den naříkat přede dveřmi.“ SKŘEJPEK, M. Prameny ř́mského práva. Praha: Lexis Nexis, 2004, s. 33.

6 SKŘEJPEK, Ius et religio, s. 165-175.

7 „Třeba však dodat, že některé takto zaměřené magické formule byly dokonce samotným římským právem využívány. Jedná se tzv. obvagulatio, o němž se rovněž zmiňuje Zákon XII desek: CUI TESTIMONIUM DEFUERIT, IS TERTIIS DIEBUS OB PORTUM OBVAGULATUM ITO /Ten, kdo nebude mít svědky, at' chodí každý třetí den s nářkem před domem/." SKŘEJPEK, Ius et religio, s. 169; BARTOŠEK, M. Encyklopedie rímského práva. Praha: Panorama, 1981, s. 221.

$8 \quad$ Plin. $N H 28,17$.

9 „,... v Zákoně XII desek najdeme tato slova: ,Kdo by očaroval plody“ a na jiném místě ,Kdo by zpíval zlou píseň"."

10 URBANOVÁ, D. Latinské proklinaci tabulky na území rímského impéria. Brno: Host: Masarykova univerzita, 2014, s. 14-15. 
proti něčemu nebo někomu s následným magickým negativním účinkem. ${ }^{11}$ Apuleius při své obhajobě užívá podobný výraz obcantata ${ }^{12}$ ve smyslu „očarovaná“ “, ${ }^{13}$ když chce poukázat na to, že chování jeho manželky Prudentilly nevykazovalo znaky pomateného ani nijak mimořádného chování, které by bylo ovlivněno magií. Nejedná se ovšem o jediný př́ípad, kdy Apuleius zmiňuje slovní derivát slovesa cantare ve smyslu ,čarovat“ nebo „očarovat“,${ }^{14}$ v rámci své obhajoby jej naopak užívá i na jiných místech. ${ }^{15}$ Stejný výraz uživá i Paulus ve svých Sentencích, ${ }^{16}$ když píše, že Sullův zákon Lex Cornelia de sicariis et veneficiis obsahoval ustanovení: qui sacra impia noctumave ut quem obcantarent, defigerent, obligarent, fecerint faciendave curaverint, aut cruci suffiguntur aut bestiis obiiciuntur. ${ }^{17}$ Rovněž v Paulově podání je sloveso obcantarent odvozeno od slovesa cantare a je spojováno s magickými praktikami. A právě odvozeniny slovesa cantare dodávají carmen (zvláště jednalo-li se o malum carmen) nadpřirozený či magický obsah.

Výraz carmen se tak z původního významu ,„píseň, báseň, modlitba či ř́kadlo“18 mění na „kouzlo, kouzelnou formuli či zaříkávadlo“ ve smyslu rytmicky pronášených slov, jež ve formální rovině sice mohou báseň, píseň či říkadlo připomínat, ovšem jejich přednes je motivován odlišným záměrem. Zvláště pak ve spojení malum carmen se jedná o škodlivé (zlé) kouzlo, jehož účelem je ublížit někomu jinému nebo poskytnout tomu, kdo je pronáší, prospěch na úkor ostatních. ${ }^{19}$ Odkazuje na zlovolnou a škodlivou magickou formuli, která je proti někomu namířena a pronášena prostřednictvím zaklínání neboli incantare nebo excantare. ${ }^{20}$ Pojem carmen je tedy nezbytné chápat v širším kontextu než pouze jako píseň nebo báseň, tedy jako zaklínadlo nebo kouzlo. Formální podobnost mezi písní či básní (carmen) a magickou formulí je nasnadě, zejména pak s ohledem na způsob jejich přednesu.

Ř́mané věřili v sílu pronesených slov a jejich účinků ve vnějším světě. Podobně nahlíželi na magickou sílu slov i Řekové. Řecké slovo pro píseň, která dokáže léčit prostřednictvím magie, se nazývala epode nebo epoide. Homér užívá tohoto výrazu, když líčí lov na kance, kterého se zúčastnil Odysseus a jeho druhové. Poté, kdy kanec Odyssea zranil, vrhli se druhové k němu a „na ránu vítězného a bohům rovného reka obvaz pak dovedně dali a kouzelným ř́ḱkadlem temný zdrželi krve mu proud“. ${ }^{21}$ Rovněž i Platón ve svých Zákonech pojednává o magii a čarodějnictví. Každý, kdo magii praktikuje za účelem způsobení

11 HOFFMAN, c. d., s. 21.

12 Apuleius, Apologia, 84: Dic tu, quibus uerbis epistulam finierit mulier obcantata, uecors, amens, amans; ...

13 „گ̌Rekni, jakými slovy zakončila svůj dopis žena očarovaná, šílená, zbavená rozumu, pomatená láskou:“ APULEIUS, L. Apologie aneb Vlastni obhajoba proti nařčení z čarodějnictví. Praha: Svoboda, 1989.

14 Křřžkův slovník překládá mimo jiné latinské sloveso canto ve spojení s carmen jako „slova kouzelná říkati““. ŘíHA, J. (ed.). Kř̌žkưv slovník latinsko-český Jan Řiha. Praha: I. L. Kober knihkupectví, 1889, s. 60.

15 Apuleius, Apologia, 48: Dudum enim, cum haec agitarentur et illi incantatam mulierem dicerent, medicus qui adfuerat abnueret, quaesisti tu nimis quam prudenter, quod mihi emolumentum fuerit incantandi.

16 Paulus Sent. 5, 23, 15.

17 „[K]dokoli provede nebo vykoná zlovolné nebo noční obětování za účelem okouzlení, proklínání, magického svázání, bude bud' ukřižován, nebo předhozen šelmám.“

18 Ř́HA, $c$. d., s. 64.

19 SKŘEJPEK, Ius et religio, s. 165-175.

20 Na tomto místě je třeba poznamenat, že někteří autoři poukazují na nedostatek důkazů prokazujících spojení mezi slovy jako carmen nebo occentare a magických praktik, či magie jako takové. HOFFMAN, $c$. $d$., s. 20-26.

21 HOMÉROS. Homérova Odysseia. Překl. VAŇORNÝ, O. Praha: Jan Laichter, 1943, s. 374 (zpěv XIX 455). 
škody (at' už majetkovou nebo škodu na zdraví) někomu jiného, bude za tuto škodu odpovědný. Tedy i praktikování negativní magie patří do sféry praktik, které jsou schopné způsobit škodu a jako takové je nezbytné je považovat za škodlivé. ${ }^{22}$ Výraz carmen ve smyslu „kouzlo“ či „zaklínadlo“ užívá v neposlední řadě rovněž Macrobius ve svých Saturnáliích, když líčí zvyk Římanů „evokovat určitými formulemi (carmen) ochranná božstva tohoto obsazovaného nepřátelského města, kde si mohli být jisti, že uspěji“‘.23

Ovšem pojem carmen jako výraz pro zaklínání či zaříkání není možné vnímat pouze v negativní rovině. Plinius starší kromě zmíněného úryvku malum carmen totiž zmiňuje rovněž odkaz na Catonův návod, jak léčit zraněnou končetinu (carmen auxiliare), což lze označit jako pomocné nebo léčebné kouzlo. ${ }^{24}$ Samotný výraz carmen tak nelze apriori vnímat pozitivně nebo negativně, vždy bude záležet, v jakém kontextu je užit. Římané tedy nepochybně rozlišovali mezi dvěma druhy praktických činností spojených s magickými rituály, které se navzdory své podobnosti setkávaly s protikladným morálním hodnocením. Jinými slovy rozlišovali mezi černou a bílou (nebo také) léčivou magií, tedy magií dovolenou. ${ }^{25} \mathrm{Na}$ tomto místě je třeba zdůraznit, že Zákon XII desek nezapovídal magii jako takovou, ale postihuje pouze ty magické techniky, které svým účinkem působí škodu jiným, nebo v přeneseném významu se někdo obohacuje na úkor ostatních, čímž jim působí škodu.

Několik dalších autorů se odvolává na zkoumanou pasáž Zákona XII desek, ovšem v poněkud odlišném kontextu, kdy se mělo v jejich pojetí jednat o ustanovení postihující pomluvy. Konkrétně Cicero v díle De re publica ${ }^{26}$ komentuje tato ustanovení slovy: Nostrae contra duodecim tabulae cum perpaucas res capite senxissent, in his hanc quoque sanciendam putaverunt: si quis occentavisset sive carmen condidisset, quod infamiam faceret flagitiumve alteri. ${ }^{27}$ Ve stejném duchu odkazuje na Cicerona i svatý Augustinus v díle De civitate Dei (O Boží obci), když se snaží podpořit své tvrzení, že i římské právo postihovalo pomluvy. ${ }^{28}$ Kapitální trest hrozící za praktikování magie nebyl v Zákoně XII desek explicitně uveden, a proto je tento Ciceronův citát důležitý, a to i ve vztahu $\mathrm{k}$ fragmentu Horatia Flacca, který ve svých Listech (Epistulae) způsob usmrcení konkretizuje, když uvádí, že se jednalo o ubičování k smrti (formidine fustis). ${ }^{29}$ Cicero odkaz na ustanovení Zákona XII desek opakuje ve svém díle Tuskulské hovory: ${ }^{30}$ Quamquam id quidem etiam

22 PLATÓN. Zákony. Překl.: NOVOTNÝ, F. Praha: OIKOYMENH, 2016, s. 345-346.

23 MACROBIUS. Saturnálie. Překl. HLAVÁČEK, J. Praha: Herrmann a synové, 2002, s. 238.

24 Plin. NH. 28, 21-22: Cato prodidit luxatis membris carmen auxiliare.

25 BARTOŠEK, c. d., s. 221.

26 Cic. De rep. 4, 10, 12.

27 „Naproti tomu našich Dvanáct desek, ačkoli stanovily trest smrti ve velmi málo případech, domnívaly se, že je třeba trestati i to, jestliže někdo zazpíval hanlivou píseň nebo složil báseň, a druhému tím způsobil hanbu a ostudu.“ CICERO, M. T. O věcech veřejných. Překl. JANOUŠEK, J. Praha: Oikoymenh, 2009, s. 165 .

28 Aug. De civ. dei 2, 9. AUGUSTINUS, A. O Boži obci knih XXII. Překl. NOVÁKOVÁ, J. Praha: Karolinum, 2007, s. 78.

29 Horat. Epistulae, 2, 1, 152-154: Poenaque lata, malo quae nollet carmine quemquam Describi: Vertere modum, formidine fustis (fustis - hůl či klacek). Není bez zajímavosti, že stejně jako Plinius st. v této pasáži i Horatius užívá vazbu malum carmen, resp. malo ... carmine, navzdory tomu, že svůj verš vztahuje $\mathrm{k}$ pomluvě.

30 Cic. Tusc. Disp. 4, 4. 
duodecim tabulae declerant, condi iam tum solitum esse carmen; quod ne liceret fieri ad alterius iniuriam lege sanxerunt, ${ }^{31}$ čímž prakticky verifikuje citovaný text $\mathrm{v}$ De re publica.

O trestu smrti za pomluvy a posměšky hovoří s odkazem na Cicerona svatý Augustinus i v jiné části svého opusu O Boží obci, když uvádí: ${ }^{32}$ at Romani, sicut in illa de re publica disputatione Scipio gloriatur, probris et iniuriis poetarum subiectam uitam famamque habere noluerunt, capite etiam plectendum sancientes, tale carmen condere si quis auderet. ${ }^{33}$ Není bez zajímavosti, že Cicero i Augustinus užívají ve spojitosti výrazu carmen sloveso condere (skládat, stavět) a nikoli slovní derivát slovesa cantare, čímž se i po významové stránce posouvá smysl zkoumaného fragmentu Zákona XII desek, jelikož zatímco Pliniův text postihuje pronášení carmen jakožto vlastní činnost, tak Cicero jde dále, když postihuje už její skládání, resp. sepis, tedy pouhou př́ipravu. To představuje významný posun, zvláště uvážíme-li, že obě slovesa vyjadřují odlišnou činnost; zatímco cantare je spojeno s verbálním projevem, tak condere spíše s projevem psaným. ${ }^{34}$

Z těchto citovaných pasáží jasně vyplývá, že Cicero a další autoři nespojovali diskutované ustanovení Zákona XII desek s magií, ale s pomluvami nebo slovními urážkami. ${ }^{35}$ Tomu pojetí by rovněž odpovídalo ustanovení Paulových Sentencí: ${ }^{36}$ Iniuriarum actio aut lege aut more aut mixto iure introducta est. Lege duodecim tabularum de famosis carminibus, membris ruptis et ossibus fractis, ${ }^{37}$ ze kterého je patrné, jak Paulus mluví o pomlouvačných nebo urážlivých básních, za které hrozí žaloba z urážky. Nehovoří tedy o kletbách či kouzlech ani o jiných magických praktikách ve spojitosti s výrazem carmen, tak jako Plinius starší. Podobně referuje i Festus, ${ }^{38}$ když píše: Occentassit antiqui dicebant quod nunc convicium fecerit dicimus quod id clare et cum quodam canore fit ut procul exaudiri possit... ${ }^{39}$ Vzhledem k tomu, že convicium patři do skupiny verbálních iniuria, napovídalo by to spíše o vztahu slovesa occentare k pomluvám nebo urážkám,

31 „Ostatně i zákony dvanácti desek dokazují, že už tenkrát bylo zvykem skládat písně: jeden z nich ustanovoval, že nesmí být skládány tak, aby druhého urážely.“ CICERO, M. T. Tuskulské hovory: Cato starší o stáři: Laelius o prátelství. Překl. BAHNÍK, V. Praha: Svoboda, 1976, s. 163.

32 Aug. De civ. dei 2, 12.

33 „Leč Římané, jak se honosí Scipio v onom dialogu O státě, nechtěli, aby jejich život a pověst byly vystaveny posměškům a křivdám básníků, stanovíce dokonce trest smrti na to, kdyby se někdo odvážil takovou píseň složit.“AUGUSTINUS, A. O Boži obci knih XXII, s. 80.

34 NOWICKA, D. Zniesławienie w prawie rzymskim. Wrocław: Prawnicza i Ekonomiczna Biblioteka Cyfrowa, 2013, s. 46-48.

35 Na druhou stranu sám Cicero užívá sousloví veneficiis et cantionibus (Cic. Brutus 217), tedy čarodějnictví a zaklínání (cantionibus od slovesa cantare - zpívat, zaklínat, přednášet) jako prostředky škodlivé magie. Paulus Sent. 5, 4, 6.

37 „Žaloba z urážky je zavedena zákonem nebo zvykem nebo obojím. Zákon XII desek trestal urážlivé básně, zlomení končetin a zlomení kostí.“

38 Fraenkel věřil, že v tomto případě vycházel Festus z komentáře Zákona XII desek právě proto, že odkazuje na convicium facere obsažené v soudobém praetorském ediktu (Ulp. D. 47, 10, 15, 2: ... „, Qui adversus bonos mores convicium cui fecisse cuiusve opera factum esse dicitur, quo adversus bonos mores convicium fieret, in eum iudicium dabo").

39 Festus 190: „Antičtí autoři používali výraz ,occentassit‘ pro to, čemu nyní ŕíkáme ,convicium‘, jelikož to probíhá s takovým stupněm křiku, že je slyšet na dálku.“ Existují ovšem významné pochybnosti o tom, že ve druhém století našeho letopočtu znal Festus (nebo na přelomu letopočtu Flaccus, ze kterého Festus vycházel) pravý význam tehdy zřejmě již archaického výrazu occentare. Jejich interpretace tohoto výrazu mohla být ovlivněna moderním chápáním pojmu convicium. NOWICKA, c. d., s. 47-48. 
tak, jak poznamenal Cicero. Z tohoto pohledu by zkoumaný fragment Zákona XII desek nepředstavovalo ustanovení proti praktikování magie, ale proti pomluvám. ${ }^{40}$

Není nijak překvapivé, že výše uvedené rozpory obsažené již v antických pramenech se staly předmětem zkoumání mnoha filologů, jazykovědců, právních historiků a jiných odborníků ve snaze je odstranit, což ovšem vedlo k patové situaci, jelikož každý argument mohl být vyvrácen rovnocenně kvalitním argumentem opačné strany stejné kategorie. Dlužno podotknout, že diskuse na toto téma stále trvá a zatím se nikomu nepodařilo zcela přesvědčivě na položenou otázku nalézt uspokojivou odpověd'. V literatuře lze vysledovat více méně čtyři různé př́istupy $\mathrm{k}$ této problematice. Zastánci prvního situaci „vyřešili“ tak, že Pliniovu i Ciceronovu klausuli oddělili a učinili z nich dvě odlišná ustanovení, ačkoli Horatiova pasáž, ${ }^{41}$ jak je výše uvedeno, jasně naznačuje zjevnou spojitost obou fragmentů. ${ }^{42}$ Jedná se převážně o autory z 19. století, i když našla své př́iznivce i v řadách pozdějších autorů. ${ }^{43}$ Zastánci druhého př́stupu předpokládají, že Zákon XII desek obsahoval jedno ustanovení, které v sobě zahrnovalo jednu skutkovou podstatu proti magii a druhou proti pomluvě, aniž by se snažili blíže vysvětlit, co je spojuje. ${ }^{44}$ Zastánci třetího př́stupu vycházeli z předpokladu, že Pliniova interpretace je správná, přičemž Cicero ${ }^{45}$ a Horatius nepochopili nebo ustanovení Zákona XII desek záměrně chybně užili či interpretovali. ${ }^{46}$ Dlužno podotknout, že jejich závěry nejsou mnohdy př́liš přesvědčivé, zvláště uvážíme-li, že to byl Cicero, kdo prohlásil, že se děti v jeho době musely učit znění Zákona XII desek nazpamět' jako básničku (ut carmen necessarium). ${ }^{47}$ Pro poslední, čtvrtý, přístup je charakteristické odmítání Pliniova fragmentu jako autentického znění Zákona XII desek a jeho zastánci se přiklání k pojetí Ciceronovu a Horatiovu, tedy že ustanovení Zákona postihovalo pomluvy a urážky, ovšem nikoli malum carmen. ${ }^{48}$ Navzdory nastíněným rozporům a četným diskuzím je třeba zmínit, že u převážné většiny současných autorů převládá názor (byt' mnohdy opřený o odlišné důvody), že jeho smyslem bylo postihnout praktikování čarodějnictví a nikoli pomluvu. ${ }^{49}$ Pro tento závěr svědčí zejména nepřekonatelné obtíže

40 HOFFMAN, c. d., s. 31-32.

41 Horat. Sat. 2, 1, 82.

$42 \quad$ Viz pozn. pod čarou č. 29.

43 Schoell publikoval pasáž Cicerona jako Tab. VIII, 1, a Pliniovu klauzuli jako Tab. VIII, 26. SCHOELL, R. Legis Duodecim Tabularum Reliqviae. Leipzig: in aedibus B. G. Teubneri, 1866, s. 140, 151; Voigt přidružil dvě klauzule Plinia s klausulí Servia v Tab. VIII, 10, a Ciceronův fragment zařadil do jiné sekce. VOIGT, c. d., s. 726-727; Fraenkel a Momigliano popírali jakoukoli potřebu jakkoli spojovat Pliniův a Ciceronův fragment. FRAENKEL, c. d., s. 185-200; MOMIGLIANO, c. d., s. 120-124.

44 Bruns zařadil Pliniovu klauzuli do Tab. VIII, 1a, a Ciceronovu pasáž pod Tab. VIII, 1b. BRUNS, C. G. - MOMMSEN, T. Fontes iuris romani antiqui. Friburgi: I. C. B. Mohr, 1887; Riccobono následuje Brunse. RICCOBONO, S. Fontes Juris Romani Antejustiniani. Florentiae: Giunti Editore, 1968; Warmington podobně jako Bruns a Riccobono, ovšem obrátil jejich pořadí. WARMINGTON, E. H. (ed.). Remains of Old Latin, Volume III. Cambridge, Mass.: Harvard University Press, 1938.

45 Cic. De rep. 4, 10, 12. Viz pozn. pod čarou č. 26.

46 STRACHAN-DAVIDSON, J. L. - MOMMSEN, T. Problems of the Roman criminal law. Oxford: Clarendon Press, 1912, s. 107; HUVELIN, c. d., s. 69-71; BECKMANN, c. d.; FRAENKEL, c. d., s. 185-200; MOMIGLIANO, c. d., s. 120-124; PHARR, C. The Interdiction of Magic in Roman Law. Transactions and Proceedings of the American Philological Association, 1932, roč. 63.

47 Cic. De leg. 2, 23.

48 HOFFMAN, c. d., s. 52-53.

49 FRANKFURTER, D. Guide to the study of ancient magic. Leiden; Boston: Brill, 2019, s. 176-180; URBANOVÁ, c. d., s. 14-15; NOWICKA, c. d., s. 35-41; DICKIE, M. Magic and magicians in the Greco-Roman 
svázané s nepřiměřeností trestu smrti za tak banální provinění, jakým je právě pomluva či urážka. Převažuje tak dnes důvěra ve správnost citace ustanovení QUI MALUM CARMEN INCANTASSIT... Zákona XII desek i jeho významu tak, jak nám jej zachoval Plinius starší $\mathrm{v}$ Naturalis historia.

\section{QUI FRUGES EXCANTASSIT}

V př́ípadě druhého posuzovaného ustanovení Zákona XII desek je situace trochu odlišná. I když i v tomto případě platí, že je Plinius ${ }^{50}$ starší jediným antickým autorem, který ustanovení QUI FRUGES EXCANTASSIT ${ }^{51}$ explicitně cituje, odkazují se na něj v tomto smyslu i někteří další autoři. Zejména pak filosof Seneka ve svém díle Quaestiones naturales se ve čtvrté knize zabývá meteorologickými jevy jako např́klad krupobitím, deštěm nebo sněhem, přičemž při této př́ležitosti zmiňuje:52 ...in xii tabulis cavetur, ne quis alienos fructus excantassit. Rudis adhuc antiquitas credebat et attrahi cantibus imbres et repelli... ${ }^{53} \mathrm{Na}$ rozdíl od Plinia staršího ovšem Seneka necituje Zákon XII desek explicitně, pouze jeho část popisuje vlastními slovy, kdy jej zejména vztahuje k nepřízni počasí, které mohlo zničit úrodu, tedy $\mathrm{k}$ diskuzi o schopnostech smrtelníků ovlivňovat počasí (k čemuž se staví velmi skepticky). Není rovněž bez zajímavosti, že se na toto ustanovení odkazuje i Apuleius ve své slavné obhajobě v případu, ve kterém byl obviněn z praktikování magie, slovy: ${ }^{54}$ Magia ista, quantum ego audio, res est legibus delegata, iam inde antiquitus XII tabulis propter incredundas frugum inlecebras interdicta, igitur et occulta non minus quam tetra et horribilis. ${ }^{55}$ Apuleius se takto v rámci své obhajoby vysmívá žalobci, který jej obvinil z praktikování čarodějnictví v př́itomnosti otroků, tedy svědků. Formulaci zákona tak vlastními slovy interpretuje, i když se po obsahové stránce od Plinia a Seneky neodchyluje a nepochybně odkazuje na totéž ustanovení.

Sloveso excantare užité v tomto kontextu lze přeložit jako ,vyzpívat“. 56 V tomto smyslu uživá výraz excantare i lékař a spisovatel Marcellus Empiricus, který píše o vyzpívání nemoci z končetin a morku kostí: 57 excanto de istis membris medullis. ${ }^{58}$ Díky těmto citacím víme, že Římané věřili v reálné účinky působení písně (zaklínadla) za předpokladu, že je píseň zazpívána správným způsobem a správnou osobou. Tedy jinými slovy, verbální projev je způsobilý vyvolat adekvátní reakci ve fyzickém světě, tedy vyvolá reálný zamýšlený účinek, za kterým je píseň zpívána. I když z těchto fragmentů nevyplývá, že by se muselo nutně jednat o magické působení, tak si stačí uvědomit, v jakém kontextu dochází k užití

world. London - New York: Routledge, 2003, s. 137-139; KIPPENBERG, H. Magic in Roman Civil Discourse: Why Rituals Could be Illegal. In: Envisioning Magic. Leiden: BRILL, 1997, s. 144-147; RIVES, Magic in the XII Tables Revisited, s. 270-290.

50 Plin. $N H 28,14-17$.

51 „Kdo by očaroval plody.“ SKŘEJPEK, Prameny řmského práva, s. 43.

52 Sen. N. Q. 4, 7, 2-3.

53 „...ve dvanácti deskách je varování, že nikdo nesmí zaklínat úrodu jiného. Nevzdělaní předkové věřili, že boưre mohla být přivolána či rozehnána kouzly.“

54 Apul. Apol. 47, 3.

55 „Tuhle magii, pokud je mi známo, lze stíhat podle zákonů, už v dávných dobách ji zakazovaly zákony dvanácti desek pro neuvěřitelnou moc, kterou má na lákání polních plodin z cizího pole na vlastní. Je tedy stejně tajná jako odporná a strašná.“

56 Předpona „ex“ znamená „,ven“ nebo „vně“ a sloveso cantare lze přeložit jako „zpívat“.

57 Marcellus 15, 11 .

58 „...vyzpívávám tě z těchto končetin, z morku kostí.“ 
slova excantare, kdy uvedené citace jasně naznačují, že toto sloveso znamená „odstranit pomocí zpěvu (zaklínadla)“, a v př́ípadě diskutovaných plodin nebo úrody pak „odstranění plodin pomocí zpěvu (zaklínadla)“, v rámci čehož už nelze pochybovat o nadpřirozených konotacích spojených s diskutovaným fragmentem. Servius je v otázce výkladu výrazu excantare konkrétnější, když ř́ká: 59 ...excantare est magicis carminibus obligare. ${ }^{60}$ Podle něj znamená slovo excantare více než očarovat písní (zaklínadlem); vysvětluje jej jako schopnost někoho svázat nebo připoutat magickými prostředky.

S fragmentem QUI FRUGES EXCANTASSIT úzce souvisí další Serviův odkaz na text Zákona XII desek, ${ }^{61}$ který se dochoval v jeho komentáŕi Vergiliovy Eklogy, ${ }^{62}$ který ten Pliniův významově doplňuje: ${ }^{63}$...neve alienam segetem pellexeris. ${ }^{64}$ Klíčové slovo pellexeris je nezbytné vnímat jako určitý druh manipulace (sváděním, lákáním či vábením), což je patrné zejména v Ciceronově pasáži Pro Cluentio: Animum adulescentis, nondum consilio ac ratione firmatum, pellexit eis omnibus rebus, quibus illa aetas capi ac deliniri potest. ${ }^{65}$ Podobně poznamenal Tacitus o Augustovi: ${ }^{66}$ ubi militem donis, populum annona, cunctos dulcedine otii pellexit. ${ }^{67}$ Obě tyto pasáže odrážejí podřízenost vůle objektu nad vưlí subjektu. Vidíme tedy, že osoba, která vykonává akci, získává kontrolu nad osobou, vůči které je vykonávána. To, co v Serviovi nacházíme, je tedy metaforické nebo rozšriřené užití výrazu pellicere s jasnou konotací, že zrno bude magicky podřízeno vůli kouzelníka. ${ }^{68}$ $\mathrm{V}$ tomto konkrétním případě sloveso pellicere naznačuje, že přenos plodin byl proveden jinými prostředky než fyzickou silou. 69

Z Augustinova odkazu ${ }^{70}$ na Ciceronův komentář Zákona XII desek obsažený v nedochované pasáži čtvrté knihy De re publica můžeme předpokládat, že výše uvedené ustanovení zákona rovněž postihovalo hrdelním trestem jednání za pomoci kouzelných technik, které by mělo za cíl přenos úrody z pozemku. Sv. Augustin konkrétně píše: Atque satas alio uidi traducere messes, eo quod hac pestifera scelerataque doctrina fructus alieni in alias terras transferri perhibentur, nonne in duodecim tabulis, id est Romanorum antiquissimis legibus, Cicero commemorat esse conscriptum et ei, qui hoc fecerit, supplicium constitutum? ${ }^{71}$ Jak je patrné, kapitální trest hrozil nejen dle fragmentu QUI MALUM CARMEN

\footnotetext{
59 Serv. Ad Ec. 8, 71.

$60 \quad$ „..excantare znamená svázat někoho magickým kouzlem.“

61 Podobně (i když jinými slovy) odkazuje na toto ustanovení i římský básník Tiballus, který konkrétně uvádí: cantus vicinis fruges traducit ab agris (,písně přenáší výhonky ze sousedova pole“). SKŘEJPEK, Ius et religio, s. 171.

62 Serv. Ad Ec. 8, 99.

63 Lex Duodecim tabularum, Tab. VIII, 8b.

64 „....ani cizí sadbu nepřeváděj“. SKŘEJPEK, Prameny řimského práva, s. 43.

65 „Svedla mysl mladého muže, protože ještě nebyla korigována střízlivostí a rozumem, a to prostřednictvím všech těch věcí, kterými lze tuto věkovou skupinu zajmout a svádět.“

66 Tac. Ann. 1, 2.

67 „...jakmile však získal vojsko dary, lid obilím, všechny sladkým mírem...“ TACITUS, C. Letopisy. Překl. MINAŘÍK, A. - HARTMANN, A. Praha: Svoboda, 1975, s. 21.

68 HOFFMAN, $c$. d., s. 66.

69 RIVES, Magic in the XII Tables Revisited, s. 270-290.

$70 \quad$ Aug. De civ. dei 8, 19.

71 „Prostředky magického umění ... může být sklizeň přemístěna na cizí pole. Nezaznamenal Cicero skutečnost, že Zákon XII desek stanovoval trest smrti tomu, kdo tak učinil?““
} 
INCANTASSIT, ale též dle fragmentu QUI FRUGES EXCANTASSIT, tedy všechny známé způsoby praktikování magie byly dle Zákona XII desek postihovány stejným způsobem.

V této souvislosti je rovněž nutné zmínit zajímavý soudní př́ípad, který zachytil Plinius starší ve své knize Naturalis historia. ${ }^{72}$ Př́ípad pojednává o propuštěnci C. Furiovi Cresimovi, který byl obviněn z čarodějnictví podle zkoumaného zákonného ustanovení svými sousedy, kteří si nedokázali jinak vysvětlit bohatost jeho úrody v porovnání se svými výpěstky, zvláště když Cresimus hospodařil na pozemku menším. V den konání soudu přinesl Cresimus veškeré své zemědělské nářadí, udržované v dobrém stavu, rovněž přivedl i svou čeled', stejně tak dobře zaopatřenou a živenou, a dobytek ve výborné kondici. Na svou obhajobu pak pravil: „Toto jsou, Quirité, má kouzla a nemohu vám sem přinést a ukázat svou noční práci, bdění a pot."73 Soud následně uznal jeho nevinu, jelikož prokázal, že neuživá žádnou magii, nýbrž racionálních prostředků, kterými dosahuje vysoké sklizně. ${ }^{74}$ Tato zmínka nenechává nikoho na pochybách, proti jakému jednání míří, a je to právě užití negativní magie v osobní prospěch, které je postihováno.

V mnoha společnostech, kde se etablovalo zemědělství jako hlavní zdroj obživy (do těchto společností patří nepochybně i raný Řím), patří neštěstí spojená s neúrodou mezi nejobávanější formy neštěstí postihující celou společnost. V takových existuje často představa, že úroda či neúroda prímo závisí na působení čarodějů a nadpřirozených bytostí. ${ }^{75}$ Tam, kde se předpokládá, že božské bytosti mají okamžitý vliv na úspěch sklizně, si je lidé předcházejí a často provádějí všechny komplikované rituály sloužící k tomu, aby je potěšily, přičemž i kvalita plodin může být považována za závislou na řádném provádění těchto rituálů odpovídajícími osobami. Kromě toho může úspěch také záviset na správném dodržování vzorců chování, které potěší bohy, a sice všemi př́slušníky dané komunity. ${ }^{76}$ Fragment Zákona XII desek QUI FRUGES EXCANTASSIT naznačuje podobnou obavu z nadpřirozeného působení čarodějů a nadpřirozených bytostí na úrodu, což představuje zřejmě stěžejní důvod, proč bylo nezbytné takové jednání zapovědět zákonem a uložit za něj kapitální trest. Raná římská společnost, která ještě nemohla využívat dodávek obilí ze Sicílie a Egypta, byla totiž na vlastních výpěstcích plně a existenčně závislá. Obava z neúrody se podobným zpo̊sobem promítla do tzv. Cresimova př́padu, který byl podle zmíněného fragmentu Zákona XII desek souzen. I když se jedná o případ až z období císařského Ríma, věřili žalobci, že za nízkou úrodu může černá magie, což dokládá přetrvávající víru v neštěstí zapř́íčiněné čarodějnictvím.

72 Plin. NH 28, 41.

73 Veneficia mea, Quirites, haec sunt, nec possum vobis ostendere aut in forum adducere lucubrationes meas vigiliasque et sudores. (Plin. NH 18, 41-43).

74 Není bez zajímavosti, že Gluckman referuje o podobných případech z kmenové společnosti, kde vyšší zemědělská produkce vede k závisti a obvinění z čarodějnictví, které udržuje rovnostářský základ hned dvěma způsoby: nejenže prosperující člověk žije v obavě z hrozícího obvinění z čarodějnictví, ale také se obává závisti samotných čarodějů. GLUCKMAN, M. Politics, Law and Ritual in Tribal Society. Oxford: Basil Blackwell, 1965, s. 59.

75 ROBERTS, S. A. Order and dispute: an introduction to legal anthropology. New Orleans: Quid Pro Books, 2013, s. 77.

76 Tamtéž. 


\section{Závěr}

Magie a právo se $\mathrm{v}$ archaických společnostech vždy významně prolínaly, vzájemně ovlivňovaly a v neposlední řadě i doplňovaly. Zákon XII desek s magií, jakožto sociální kategorií a fenoménem, pracuje převážně v souvislosti s jejími negativními projevy, tj. čarodějnictvím, zejména ve snaze je omezit prostřednictvím dvou ustanovení VIII. desky: QUI MALUM CARMEN INCANTASSIT a QUI FRUGES EXCANTASSIT. I když jsou ř́mské prameny zejména ve vztahu $\mathrm{k}$ prvně jmenovanému fragmentu nejednotné $\mathrm{v}$ tom, zda postihuje magické praktiky nebo pomluvy či urážky, v celkovém souhrnu a při komplexním hodnocení lze přisvědčit spíše závěru, že se jednalo o ustanovení snažící se eliminovat černou magii a její negativní antisociální projevy. Jak obě citovaná ustanovení naznačují, Římané totiž neochvějně věřili v účinky magie, stejně jako věřili v negativní následky, které může její praktikování způsobit. V souladu s touto vírou uvedená ustanovení začlenili Decemvirové do Zákona XII desek ve snaze potřít černou magii na legislativní úrovni. Není bez zajímavosti, že zůstala v platnosti spolu s celým Zákonem XII desek až do konce antiky, jelikož nikdy nedošlo k jeho explicitní derogaci, i když po vydání Sullova zákona Lex Cornelia de sicariis et veneficiis $\mathrm{v} 1$. století př. $\mathrm{n}$. l. vyšla obě ustanovení z praktického užívání, jelikož byla zcela nahrazena textem nového zákona. 